\title{
Impact of Agritourism as Perceived by Multiple Stakeholders
}

\author{
D. K. Krishna*, N. V. Kumbhare, J. P. Sharma, D. U. M. Rao, D. K. Sharma, \\ Pramod Kumar and Arpan Bhowmik
}

ICAR-Indian Agricultural Statistical Research Institute, New Delhi-110 012, India

*Corresponding author

\section{Keywords}

Agri-tourism,

Hosts, Visitors, Employment, Mandays/year, Socioeconomic changes

\section{Article Info}

Accepted:

20 June 2020

Available Online:

10 July 2020

\section{A B S T R A C T}

The present study was conducted to assess the impact of agritourism as perceived by its stakeholders. The sample comprised of forty-five Agritourism Centres (ATCs) drawn from two states i.e. Maharashtra $(n=30)$ and Goa $(n=15)$. The total number of visitors selected for the study was 200, thus consisting of 100 visitors each from respective states. It followed an ex-post facto research design and was purposively conducted in Maharashtra and Goa. The impact was measured in terms of change in employment days and perceived overall socio-economic changes. An average number of employment days in Maharashtra and Goa had increased from 149 to 202 man-days/year and 117 to 208 man-days/year viz. after 2016. Significant changes were observed in the installation of new irrigation system and new farm structure for activities and games in Maharashtra whereas in Goa, ATC farms witnessed significant improvement in the installation of new processing and postharvesting equipment and arrangements for entertainment along with the installation of a new irrigation system. Both the ATC hosts showed significant social changes in social participation, increase in external contacts, and recognition and awards. A significant difference was observed among the compared benefits as perceived by tourists in terms of learning more about nature, to think about their values, recalling good times from the past and to have a change from their daily routine.

\section{Introduction}

Agriculture and its allied activities are on the brink of a change for both the farmers as well as consumers. Agritourism is one such activity where people from the outside visit a farm on vacation. Agritourism has been defined and labelled in various ways in the literature. Philips et al., (2010) provide a typology of definitions of Agritourism. It may be defined as "rural enterprise which incorporates both a working farm environment and a commercial tourism component" (Weaver and Fennel 1997, McGehee 2007). Barbieri and Mshenga (2008) referred to agri-tourism as "any practice developed on a working farm to attract visitors." Agri-tourism is the nascent growing sector in the tourism industry in recent years. The concept has been successfully implemented in Indian states like Maharashtra, Kerala, Rajasthan, Goa, Jharkhand, Gujarat, Punjab and Himachal Pradesh. 
It has become a new avenue for earning income for rural farmers. Farm visits, farm stays and trail visits are gradually picking up amongst tourists to experience something different from clichéd sightseeing packages of a destination. It has brought numerous changes in the farm as well as socio personal life of hosts. McCool and Martin (1994) reported that host community view tourism provides socio-cultural benefits to the community such as tourism creates opportunities for cultural exchange. Chadda and Bhakare (2012) reported that agritourism creates a win-win situation for both the farmers as well as the tourists.

The farmers benefit by deriving an extra source of income and tourist hunger for a natural and peaceful environment is satisfied. Frequency of income generation increases from once a year to once a week. Gender bias is reduced as both male and female get equal opportunities to earn from the employment generated through various allied activities like Emu, organic and dairy farming. Yavanarani (2013) reported that rural tourism creates employment for rural people and generate income for them. The villagers can provide better food and education for their children and their quality of life will improve. They have a supplementary source of income along with their agricultural income. The rural people can learn from modern culture and can overcome some blind traditional values and beliefs which pose a challenge to overall development. The present study aims at assessing and quantifying the socio-economic changes as perceived by different stakeholders.

\section{Materials and Methods}

The study was conducted in purposively selected Maharashtra and Goa states during 2016-17 to 2018-19 by following ex-post facto research design with the concept of before-after studies. The sample respondents in the present study comprised of forty-five agri-tourism centres drawn from both states (30 from Maharashtra and 15 from Goa). The total number of 200 agri-tourists (visitors) includes 100 visitors each from respective states selected for the study. The socioeconomic impact was measured in terms of employment generation and overall socioeconomic changes in terms of farm-material possession, expenditure pattern, farm changes, standards of living, operator's economy and social participation. For the present study the year 2016 was selected as a benchmark. The three years before 2016 is considered as "before" data whereas changes after 2016 are considered after. After consultation with agritourism experts and agencies working in the agritourism field, the researcher found that after 2016 there was significant growth and development in the field. Moreover, some of the ATCs that are surveyed are established latest in 2016. Hence this benchmark suited for the study. It is more convenient for the respondents to recall the recent 5-6 years than decade-old data. Employment generation was measured as the total number of man-days employed on the respondent agri-tourism host's farm in a year. In this study, the total number of man-days used on the respondent agri-tourism host's farm in a year before adoption and three years after agri-tourism was found out to compare if there was any change (increase/decrease) in the employment generation on account of adoption. The change was measured separately for ATCs of Maharashtra and Goa. The statistical significance of the change in employment generation was measured using t-test. McNemar test is used to analyze pretest-posttest study designs, as well as being commonly employed in analyzing matched pairs and case-control studies. Here, in the study, it is used to find the differences of parameters of the social and overall impact of agri-tourism on hosts. The personal benefit is 
also a component of impact assessment as perceived by tourists in both states was measured on a five-point continuum from no benefit to highly beneficial. Mann-Whitney U testis used to compare the perceived personal benefits from agri-tourism centres between Maharashtra and Goa tourists. A semistructured interview schedule containing appropriate questions for data collection was prepared. The data were collected by personal interview as well as focused group discussion methods. The Statistical Package for the Social Sciences (SPSS Version 17) was used to perform the statistical analysis.

\section{Results and Discussion}

\section{Impact of agritourism on employment} generation

Employment is an indication of economic activity engaged in any sector. Here, in the sampled 45 ATCs combined of both states, the data was collected according to the timeline and categorised as before and after.

Impact of agritourism on the generation of employment is given in table 1. An average number of employment days in Maharashtra has increased from 149 to 202 man-days/year after 2016. There was also an increase in average employment days from 117 to 208 man-days/year in Goa after the same time. The t-test results indicate that the increase in the number of employment days per year is statistically significant at 1 per cent probability level.

Labour is an important component of any enterprise. Agriculture being labour intensive activity needs the economic advantage of employment in itself. After interpreting the results of the above table it can be ascertained that the considerable increase in the employment generation in the agritourism is due to its growth and development. It suggests that positive impact is seen in the sampling area in terms of employment generation. One of the benefits of agritourism is Employment opportunities to the farmers including their family members and other local youths (Chandrashekhara, 2018). Agritourism can contribute in a big way in optimally utilizing the agricultural land in India, generate additional income to the farmers and provide employment (Chadda and Bhakare, 2012). The above findings are consistent with observations of Flanigan et.al. (2015); Hara and Naipaul (2008).

\section{Overall socio-economic changes as perceived by ATC operators/hosts}

The overall socio-economic impact of agritourism on hosts/operators was conceptualized as a combination of belowmentioned parameters such as material changes, changes in expenditure pattern, overall farm changes, changes in standard of living, changes in financial status and change in social participation. Some of the parameters are measured categorically and few on a continuum. The results as per each component/parameter are discussed in the following paragraphs.

The results in table 2 show the socioeconomic changes before and after the ATC initiative in the sampling area of Maharashtra. The first parameter i.e. material changes were measured on a five-point continuum that starts with 1-no change to 5-greatly changed. McNemar's test statistic reveals that there were significant changes in the adoption of innovative technologies by ATCs such as drip irrigation and modern structure for tourism and entertainment were installed to great extent due to concept of agritourism. Whereas borewell and other vehicles were already present with them, hence no significant changes in their ownership pattern were observed. Agribusiness ventures require high 
investment at initial stages but once the business crosses breakeven point, the returns will bring changes in the material possession (Prabhakar, 2010). These findings are consistent with Huff and Munro (1985); Karampela et al., (2016).

The second component i.e. changes in expenditure pattern which was measured on a continuum reveal that there was a significant increase in the expenditure for education. This was because they spent savings from the extra income generated from ATC to the education of their family members as well as for themselves under training programmes.

Overall farm changes are the third component in the socio-economic impact of agritourism on operators revealed that there were significant changes in improving their existing lands, diversifying the cropping system and leasing out extra lands for cultivation. This was observed because agritourists expected that the farms must rich in crop diversity and high standard of agriculture with multi enterprises in it. Moreover, the farmers also felt that without improving their lands regularly it is difficult to stay in the business. The good returns over the years also a motivation factor for improving lands and focusing on agritourism.

Changes in standard of living were measured on a five-point continuum with the 1-no change to 5-to a great extent. The data revealed that there was no significant difference in their standard of living due to agritourism.

Changes in their financial status revealed that there was a significant change in their capacity to repaying the old loans, more intention of savings and invested money on other enterprises in case of Maharashtra sampled agritourism centres. There was no significant change in incurring losses and debts. Although the majority of agritourism operators do not receive direct sales from this activity, they perceive it as important for the continued operation of their farm. Agritourism is also perceived as having a positive impact on farm profits (Tew and Barbeiri, 2012). Changes in social participation are one of the most important components of the socio-economic impact of agritourism. The data in the table 2 Revealed that significant improvements have been observed in their social participation in latest years as a result of agrotourism. Increment in outside contacts, awards and recognition were perceived as highly significant factors in the overall social participation. These findings are in line with Barbieri and Mshenga (2008) who discussed in their study that social participation is both ingredient and outcome of any successful agritourism.

The data in table. 3 revealed the significant changes in socio-economic conditions of agritourism hosts/owners in Goa. There were highly significant changes in the adoption of innovative technologies by ATCs such as new processing and post-harvest equipment and modern structure for tourism and entertainment were installed to great extent to fulfil the concept of agritourism. There was an also significant change noticed in case of installation of drip irrigation in recent years due to agritourism. Whereas borewell and other vehicles were already present with them, hence no significant changes in their ownership pattern were observed. These results indicate that the venture is not only improving farmers' condition but also changing their behaviour and attitude towards innovative technologies. They are more interested to adopt technologies both to showcase to the tourists and enhance crop productivity with high efficiency.

The second component i.e. changes in expenditure pattern revealed that there were 
no significant changes in it except for a change in the increase in expenditure for social functions. This was because they spent savings from the extra income generated from ATC to social activities and festivals which also included their tourists. Moreover, the Goa farm tourism units were service oriented and large area based. Hence agritourism is an added advantage to attract all type of tourists other than tourists who seek entertainment.

Overall farm changes are the third component in the socio-economic impact of agritourism on operators revealed that there were significant changes in improving their existing lands. All others were perceived as not so significantly changed in recent years just because of agritourism. This was observed since Goa farm is more focused on horticultural crops such as spices, flowers, plantations, fruit orchards and processing plants. They can't change the crop diversity regularly as in the case of Maharashtra. Since the main occupation in Goa is tourism, therefore they try to keep intact that biodiversity. But, they improved their lands in terms of hygiene and sanitation, levelling of undulated barren lands for showcasing some crops and installing an innovative irrigation system.

There is no dearth of water in Goa as such observed but because of the farm tourism unit, owners felt that the irrigation unit would improve yield and enhance the efficiency along with a component of showcasing to tourists.

Changes in standard of living data reveals that there was no significant difference observed in their standard of living due to agritourism as such.

Changes in their financial status revealed that there was a no significant change in any of its components. It is observed due to the fact that
Goa ATCs were well established and economically sound farms which have recently included the component of agritourism within them. Hence, the agritourism unit has only brought behavioural changes among the owners rather than significant economic change. Although the majority of agritourism operators do not receive direct sales from this activity, they perceive it as important for the continued operation of their farm for promotion of ayurveda and naturopathy.

Changes in social participation are one of the most important components of the socioeconomic impact of agritourism. The results (table.3) revealed that notable improvement in their social participation as observed over the recent years due to agritourism than before. Increment in outside contacts, improvement in communication with hosts, subscription to agricultural magazines and awards and recognition were perceived as highly significant factors in the overall social participation.

This was observed due to focus on agriculture along with other entertainment aspects in Goa. The major social change notable here is the subscription to agricultural magazines which is a sign of positive impact of agritourism on the owners in the recent years. These findings are in line with Barbieri and Mshenga (2008) who discussed in their study that social participation is both ingredient and outcome of any successful agritourism.

\section{Personal benefits from agritourism farms as perceived by agritourists}

These are the effect of agritourism bestowed upon tourists as an outcome of this enterprise to other stakeholders than farmers. Table 4 is also evident for the significantly differing benefits from each other along with varied preferences among themselves. 
Table.1 Changes in employment generation as the impact of agritourism initiative

\begin{tabular}{|l|l|c|c|c|c|c|c|}
\hline Sl & Descriptive & \multicolumn{2}{|c|}{ Maharashtra } & \multicolumn{2}{|c|}{ Goa } & \multicolumn{2}{c|}{ Total } \\
\hline No & statistics & Before & After & Before & After & Before & After \\
\hline $\mathbf{1}$ & Mean & 149.10 & 201.80 & 116.75 & 207.78 & 265.85 & 409.58 \\
\hline $\mathbf{2}$ & SE & 10.11 & 10.51 & 8.83 & 13.03 & 18.94 & 23.54 \\
\hline $\mathbf{3}$ & SD & 63.96 & 66.48 & 55.82 & 82.41 & 59.89 & 74.13 \\
\hline $\mathbf{4}$ & CV & 0.43 & 0.33 & 0.48 & 0.40 & 0.23 & 0.21 \\
\hline $\mathbf{5}$ & Skewness & 1.32 & 0.71 & 0.59 & 1.67 & 0.02 & 0.58 \\
\hline $\mathbf{6}$ & Range & 257.00 & 238.00 & 256.00 & 426.00 & 262.00 & 332.00 \\
\hline $\mathbf{7}$ & Minimum & 68.00 & 112.00 & 15.00 & 99.00 & 166.00 & 422.00 \\
\hline $\mathbf{8}$ & Maximum & 325.00 & 350.00 & 271.00 & 525.00 & 357.00 & 729.00 \\
\hline $\begin{array}{l}\text { t-test results for } \\
\text { change in } \\
\text { employment }\end{array}$ & States & $\mathbf{t}$-stat & $\begin{array}{l}\text { P(T<=t) } \\
\text { two-tail }\end{array}$ & $\begin{array}{c}\text { t Critical } \\
\text { two-tail }\end{array}$ & $\begin{array}{l}\text { Level of } \\
\text { Significance }\end{array}$ \\
\hline & Maharashtra & 6.865 & $<0.001$ & 2.023 & & $* *$ \\
\hline
\end{tabular}

(Before $=$ three years average from 2013 to 2015, after= Three years average from 2016 to 2018)

Note: ** Significance at 1 per cent level (Figures in man days)

Table. 2 Components of socio-economic impact of agritourism and its significance in Maharashtra $\mathrm{n}=30$

\begin{tabular}{|l|l|c|c|c|}
\hline $\begin{array}{l}\text { A. Material Changes } \\
\text { SI } \\
\text { No. }\end{array}$ & Particulars & $\begin{array}{c}\text { McNemar } \\
\text { Statistic }\end{array}$ & $\begin{array}{c}\text { Extract } \\
\text { Pr>= S }\end{array}$ & $\begin{array}{c}\text { Level of } \\
\text { significance }\end{array}$ \\
\hline $\mathbf{1}$ & Pump set/ Bore well & 6.000 & 0.0610 & NS \\
\hline $\mathbf{2}$ & Tractor/ Van/ vehicle/bullockart & 5.000 & 0.0625 & NS \\
\hline $\mathbf{3}$ & Drip/sprinkler irrigation system & 23.000 & $<0.001$ & $* *$ \\
\hline $\mathbf{4}$ & $\begin{array}{l}\text { Structures for activities and games } \\
\text { like swings, wooden furniture, lawns } \\
\text { etc }\end{array}$ & 21.000 & $<0.001$ & $* *$ \\
\hline B. Change in expenditure pattern & & & \\
\hline $\mathbf{1}$ & Food items & 1.471 & 0.3323 & NS \\
\hline $\mathbf{2}$ & Education & 6.004 & 0.0020 & $*$ \\
\hline $\mathbf{3}$ & Healthcare & 5.261 & 0.0647 & NS \\
\hline $\mathbf{4}$ & Social Function & 0.818 & 0.5488 & NS \\
\hline C. Overall farm changes & 1.600 & 0.3438 & NS \\
\hline $\mathbf{1}$ & Purchased new lands & 5.333 & 0.0386 & $*$ \\
\hline $\mathbf{2}$ & Improved the existing lands & 13.500 & $<0.001$ & $*$ \\
\hline $\mathbf{3}$ & Diversified cropping system & 5.762 & 0.0266 & $*$ \\
\hline $\mathbf{4}$ & Leased out lands for cultivation & 1.333 & 0.3877 & NS \\
\hline $\mathbf{5}$ & Purchased additional livestock & 0.889 & 0.4807 & NS \\
\hline D. Changes in standards of living & &
\end{tabular}




\begin{tabular}{|c|c|c|c|c|}
\hline 2 & Had better nutritious food & 1.471 & 0.3323 & NS \\
\hline 3 & Spent more money on clothing & 3.769 & 0.0923 & NS \\
\hline 4 & $\begin{array}{l}\text { Spent more for religious, marriages } \\
\text { and other ceremonies }\end{array}$ & 0.818 & 0.5488 & NS \\
\hline \multicolumn{5}{|c|}{ E.Changes in financial status } \\
\hline 1 & Repaid old loans & 6.390 & 0.0520 & $*$ \\
\hline 2 & Increased savings/ deposits & 5.000 & 0.0504 & $*$ \\
\hline 3 & Invested money on other enterprises & 7.316 & 0.0034 & $*$ \\
\hline 4 & Incurred loss and debts & 2.000 & 0.5000 & NS \\
\hline \multicolumn{5}{|c|}{ F. Change in social participation } \\
\hline 1 & $\begin{array}{l}\text { Many farmers approach me for } \\
\text { agritourism related information }\end{array}$ & 2.25 & 0.2101 & NS \\
\hline 2 & Emerged as a leader/ progress farmer & 1.00 & 0.4545 & NS \\
\hline 3 & $\begin{array}{l}\text { Become effective communicator as } \\
\text { agritourism host }\end{array}$ & 2.25 & 0.2101 & NS \\
\hline 4 & Outside contacts increased & 23.14 & $<0.001$ & $* *$ \\
\hline 5 & $\begin{array}{l}\text { Subscribed farm publications and } \\
\text { general publications }\end{array}$ & 6.81 & 0.0488 & NS \\
\hline 6 & Received awards/ recognition & 12.56 & $<0.001$ & $* *$ \\
\hline 7 & $\begin{array}{l}\text { Served as a resource person in the } \\
\text { training programme on agritourism }\end{array}$ & 4.00 & 0.1250 & NS \\
\hline
\end{tabular}

Note: ** Significance at 1 per cent level; * Significance at 5 per cent level

Table. 3 Components of socio-economic impact of agritourism and its significance in Goa $\mathrm{n}=15$

\begin{tabular}{|c|c|c|c|c|}
\hline \multicolumn{5}{|c|}{ A. Material Changes } \\
\hline $\begin{array}{l}\text { Sl } \\
\text { No. }\end{array}$ & Particulars & $\begin{array}{l}\text { McNemar } \\
\text { Statistic }\end{array}$ & $\begin{array}{l}\text { Extract } \\
\text { Pr }>=S\end{array}$ & $\begin{array}{l}\text { Level of } \\
\text { significance }\end{array}$ \\
\hline 1 & Pumps set/ Bore well & 2.00 & 0.5000 & NS \\
\hline 2 & Tractor / Van/ vehicle/bullock cart & 1.00 & 1.0000 & NS \\
\hline 3 & Drip /sprinkler irrigation system & 9.00 & 0.011 & $*$ \\
\hline 4 & $\begin{array}{l}\text { New Processing and post harvest } \\
\text { equipments }\end{array}$ & 14.00 & $<.0001$ & $* *$ \\
\hline 5 & Farm shed/cottages & 3.00 & 0.2500 & NS \\
\hline 6 & Cold storage structure & 2.00 & 0.5000 & NS \\
\hline 7 & $\begin{array}{l}\text { Structures for activities and games like } \\
\text { swings, wooden furniture, lawns etc }\end{array}$ & 17.00 & $<.0001$ & $* *$ \\
\hline \multicolumn{5}{|c|}{ B. Change in expenditure pattern } \\
\hline 1 & Food items & 1.47 & 0.3323 & NS \\
\hline 2 & Education & 0.69 & 0.5811 & NS \\
\hline
\end{tabular}




\begin{tabular}{|c|c|c|c|c|}
\hline 3 & Healthcare & 0.89 & 0.4807 & NS \\
\hline 4 & Social Function & 5.56 & 0.0309 & $*$ \\
\hline \multicolumn{5}{|c|}{ C. Overall farm changes } \\
\hline 1 & Purchased new lands & 0.40 & 0.7539 & NS \\
\hline 2 & Improved the existing lands & 6.37 & 0.0192 & $*$ \\
\hline 3 & Diversified cropping system & 2.78 & 0.1797 & NS \\
\hline 4 & Leased out lands for cultivation & 0.11 & 1.0000 & NS \\
\hline 5 & Purchased additional livestock & 1.333 & 0.3877 & NS \\
\hline \multicolumn{5}{|c|}{ D.Overall changes in standards of living } \\
\hline 1 & Provided better education to children & 2.41 & 0.2006 & NS \\
\hline 2 & Had better health care & 2.67 & 0.2188 & NS \\
\hline 3 & Had better nutritious food & 5.00 & 0.0625 & NS \\
\hline 4 & Spent more money for clothing & 3.00 & 0.2500 & NS \\
\hline 5 & $\begin{array}{l}\text { Spent more for religious, marriages and } \\
\text { other ceremonies }\end{array}$ & 4.00 & 0.205 & NS \\
\hline \multicolumn{5}{|c|}{ E.Overall economic changes } \\
\hline 1 & Repaid old loans & 4.00 & 0.1250 & NS \\
\hline 2 & Increased savings/ deposits & 4.45 & 0.0654 & NS \\
\hline 3 & Invested money on other enterprises & 0.67 & 0.6875 & NS \\
\hline 4 & Incurred loss and debts & 4.45 & 0.0654 & NS \\
\hline \multicolumn{5}{|c|}{ F. Change in social participation } \\
\hline 1 & $\begin{array}{l}\text { Many other farmers approach the owner } \\
\text { for agritourism related information }\end{array}$ & 6.00 & 0.0313 & * \\
\hline 2 & Emerged as a leader/ progress farmer & 2.31 & 0.35 & NS \\
\hline 3 & $\begin{array}{l}\text { Become effective communicator as } \\
\text { agritourism host }\end{array}$ & 13.29 & $<0.001$ & $* *$ \\
\hline 4 & Outside contacts increased & 14.00 & $<0.001$ & $* *$ \\
\hline 5 & $\begin{array}{l}\text { Subscribed farm publications and } \\
\text { general publications }\end{array}$ & 8.33 & 0.0063 & $* *$ \\
\hline 6 & Received awards/ recognition & 5.00 & 0.0625 & NS \\
\hline 7 & $\begin{array}{l}\text { Served as a resource person in the } \\
\text { training programme on agritourism }\end{array}$ & 3.00 & 0.25 & NS \\
\hline
\end{tabular}

Note: ** Significance at 1 per cent level; * Significance at 5 per cent level; NS: Non-significant 
Table.4 Comparison of the Perceived personal benefits from agritourism farms between Maharashtra and Goa tourists $n=200$

\begin{tabular}{|l|c|c|c|c|c|}
\hline Personal Benefits & $\begin{array}{c}\text { Maharashtra } \\
\text { (Sum of ranks) }\end{array}$ & $\begin{array}{c}\text { Goa } \\
\text { (Sum of } \\
\text { ranks })\end{array}$ & $\begin{array}{c}\text { Mann- } \\
\text { Whitney U } \\
\text { test }\end{array}$ & Z & p value \\
\hline $\begin{array}{l}\text { Spend time with their } \\
\text { family in farm }\end{array}$ & 9723.5 & 10376.5 & 4.676 & -0.847 & 0.397 \\
\hline Learn more about nature & 9117.0 & 10983.0 & 4.067 & -2.41 * $^{*}$ & $<0.05$ \\
\hline $\begin{array}{l}\text { Be with people having } \\
\text { similar values }\end{array}$ & 9466.0 & 10634.0 & 4.416 & -1.529 & 0.126 \\
\hline $\begin{array}{l}\text { Give their mind a rest } \\
\text { Experience new and } \\
\text { different things }\end{array}$ & 9832.0 & 10268.0 & 4.782 & -0.566 & 0.571 \\
\hline $\begin{array}{l}\text { Think about their } \\
\text { personal values }\end{array}$ & 10117.5 & 9982.5 & 4.932 & -0.175 & 0.861 \\
\hline $\begin{array}{l}\text { Recall good times from } \\
\text { the past }\end{array}$ & 10902.0 & 9198.0 & 4.148 & $-2.217 *$ & $<0.05$ \\
\hline $\begin{array}{l}\text { Enjoy the smells and } \\
\text { sounds of nature }\end{array}$ & 9458.0 & 10642.0 & 4.408 & -1.542 & 0.123 \\
\hline $\begin{array}{l}\text { Share their agritourism } \\
\text { skills }\end{array}$ & 10121 & 9979 & 4.929 & -0.184 & 0.854 \\
\hline $\begin{array}{l}\text { Have a change from their } \\
\text { daily routine }\end{array}$ & 9110 & 10990 & 4.060 & $-2.458^{*}$ & $<0.05$ \\
\hline Experience solitude & 10656 & 9444 & 4.394 & -1.571 & 0.116 \\
\hline
\end{tabular}

*significance at 5 per cent level

Mann-Whitney $U$ test revealed that visitors to Maharashtra sampled ATCs perceived 'thinking about their personal values' is important than all other possible benefits listed under the table 4. It was followed by their liking to 'recall goodtimes from past and experiencing solitude'. The situation is different Goa with the visitors' maximum preference towards the benefit of change from daily routine followed by benefit of learning from nature. The four perceived benefits among the visitors were found significantly differing between the states at $5 \%$ level of significance.

As per data in the table 4 .Visitors preferred to learn more from nature and to have change from daily routine in Goa than Maharashtra. This may be due to the fact that the former state more rich in biodiversity than latter and the tag of final destination of entertainment to Goa has made the tourists to respond in such direction. At the same time, visitors in Maharashtra preferred benefit of thinking personal values and recalling good times form past than Goa tourists. This may be due to the fact that the agritourism farm in former state is little away from cities and authentic rural life and way of life made them to form such opinions.

In conclusion the agritourism is emerging as one of the profitable agribusiness venture in modern times. Even though the impact assessment is relative and moderately quantitative but it shows visible changes in the sampled areas. Presently the sector needs policy and research backstopping that 
includes institutional interventions and government strategies and suggestions for agritourism development. Reduction of high initial investment through introducing low cost construction materials through intense research and case studies would bring the establishment cost to minimum level so that even the semi-medium and small farmers can also think of the venture. Provision of loan through PACS/ Commercial banks under MUDRA or startup scheme will encourage the young and interested farmers to take this venture. Provision of subsidy for low cost agritourism farms would strengthen as an agritourism. This would only augment the impact of this venture in positive note to enhance the income of the customers as well as reaching out to the urban tourists to bring to their roots.

\section{References}

Barbieri, C. and Mshenga, P. M. 2008. The role of the firm and owner characteristics on the performance of agritourism farms. Sociologiaruralis, 48(2), 166-183.

Chadda, D., \& Bhakare, S. (2012). Socioeconomic implications of agri tourism in India. In International Conference on Innovation, Trade and EconomicsICITE (pp. 151-155).

Chandrashekhara, Y. (2018). Agro-Tourism and Employment Opportunities in Karnataka: An Economic Analysis. Epitome: International Journal of Multidisciplinary Research, 4(3).

Fennell, D.A. and Weaver, D.B., 1997. Vacation farms and ecotourism in Saskatchewan, Canada. Journal of Rural studies, 13(4), pp.467-475.

Malkanthi, S. H. and Routray, J. K. 2012.Visitor satisfaction in agritourism and its implications for agritourism farmers in Sri Lanka. International Journal of Agricultural Management, 2(1), 17-30.

McCool, S. F., \& Martin, S. R. (1994). Community attachment and attitudes toward tourism development. Journal of Travel research, 32(3), 29-34.

McGehee, N. G. 2007. An agritourism systems model: A Weberian perspective. Journal of Sustainable Tourism, 15(2), 111-124.

Phillips, M., Thilmany-McFadden, D., and Sullins, M. 2010.Possible roles for social networking in agritourism development. Agricultural marketing report (Colorado State University.Dept. of Agricultural and Resource Economics); AMR 10-01.

Singh, S.,N.L.M. Raman and B.S. Hansra. 2017. Perspectives of Agritourism in Himachal Pradesh: A new dimension in hill agricultural diversification. Journal of Community Mobilization and Sustainable Development, 12(2): 207215.

Srivastava, S. 2016.Agritourism as a Strategy for the Development of Rural Areas Case Study of Dungrajya Village, Southeast Rajasthan, India. Journal of Medical and Dental Science Research, 3(6), 35-39.

Yavana, R. S. (2013). Stakeholders'analysis On Karaikudi As A Rural Tourism Destination (Doctoral dissertation, Kalasalingam University).

\section{How to cite this article:}

Krishna, D. K., N. V. Kumbhare, J. P. Sharma, D. U. M. Rao, D. K. Sharma, Pramod Kumar and Arpan Bhowmik. 2020. Impact of Agritourism as Perceived by Multiple Stakeholders. Int.J.Curr.Microbiol.App.Sci. 9(07): 2499-2508. doi: https://doi.org/10.20546/ijcmas.2020.907.293 